HELMINTHOLOGIA, 52, 2: 123 - 129, 2015

\title{
Changes of nematode community under monoculture wheat and wheat/jujube intercropping system in Xinjiang, Northwest China
}

\author{
Y. B. LIU, L. L. ZHANG, Q. Z. LIU*
}

Department of entomology, College of Agriculture and Biotechnology, China Agricultural University, Beijing 100193, China, *E-mail: Iqzzyx163@163.com

\section{Article info}

Received September 6, 2014 Accepted January 28, 2015

\begin{abstract}
Summary
Nematode communities in the soils of wheat (Triticum aestivum Linn.) rhizosphere grown alone and grown in jujube (Ziziphus jujuba Mill.) orchard were investigated for three years in Hetian arid area, Xingjiang Uygur Autonomous Region, northwest of China. The results showed that eu-dominant families were Rhabditidae, Cephalobidae and Aphelenchidae among 15 families and 19 genera. Nematode abundance in wheat rhizosphere soil was smaller in wheatjujube intercropping system, mainly because of lower numbers of bacterial feeders and fungal feeders. Besides, the nematode numbers of $\mathrm{cp}-1$ and $\mathrm{cp}-2$ (cp, colonizer-persister) guilds were significantly lower in wheat/jujube intercropping system than that in monoculture wheat system, due to the markedly lower numbers of Rhabditidae and Cephalobidae, although those of cp-3 and cp-4 guilds had no significant differences between monoculture and intercropping systems. Shannon-Weaver index $\left(H^{\prime}\right)$, genus dominance index $(I g)$ and structural index $(S I)$, represented soil food web diversity and structure, had no differences between monoculture and intercropping systems. Significantly lower values of Wasilewska index $(W I)$ and $P P I / M I$ in monoculture wheat than in intercropping system. It was concluded that the soil status in monoculture wheat system exhibited better soil ecosystem in compared with wheat/ jujube intercropping system.
\end{abstract}

Keywords: soil nematodes; colonizer-persister; biodiversity; maturity index; soil food web

\section{Introduction}

Although Xinjiang Uygur Autonomous Region account $17 \%$ national territory with unique light and heat resources, still only $5 \%$ arable land has been used effectively due to the desert climate (Liu et al., 2012). The consensus of planted variety crops in the limited land was more popular for the local farmers. Wheat (Triticum aestivum Linn.) is large-scale cultivated in Xingjiang, the most important area of winter wheat production in China. Nowadays wheat/jujube (Ziziphus jujuba Mill.) intercropping system are widely employed because it is benefit for soil and water conservation and improvement of environment (Zhao \& Lu, 2004).

Wheat/jujube intercropping system in Hetian improved total output and efficiency of land use, but decreased root length density and root surface area density (Zhang et al., 2013). Intercropping wheat with jujube obviously improved soil physical properties, soil micro- organisms and soil nutrient. In addition, the disease occurrence of dry-hot winds in wheat was decreased when grown in jujube orchard (Chang et al., 2012). Other studies about intercropping focused on its important cultural practices in pest control, and found that natural enemies were build up and insect pests were reduced in intercropping castors (Rao et al., 2012). In southern Africa, intercropping with sugar bean, peanut and sweet potato could reduce Meloidogyne javanica and Pratylenchus zeae infestation of sugarcane sett roots (Berry et al., 2009). India farmers grew marigold plants in land bordering vegetable crops or between the rows in order to control plant parasitic nematodes in lower level (Siddiqui \& Alam, 1987). However, there still is lack of data on long time changes of wheat rhizosphere soil nematode communities in wheat/jujube intercropping system.

Soil nematodes are very abundance and diverse in all soils, feeding on a wide range of soil organisms, the movement of soil nem- 
atodes depend on the continuity of soil water, which can reflect disturbances rapidly (Yeates \& Bongers, 1999). Besides, soil nematodes play a key role in the decomposition of soil organic matter, mineralization of plant nutrients as well as nutrient cycling, by regulating soil bacterial and fungal populations and their metabolites (Neher, 2001). It is apparently that soil nematode is one of the most influential and sensitive bioindicator of soil health. Interpretation of nematode community structure offer excellent opportunities to assess the condition of soils, and to monitor changes in the structure and function of the detritus food web of cultivation and land use changes (Bernard, 1992; Santorufo et al., 2012). There are many studies on nematode communities as bioindicator, such as continuous cropping, organic cropping, fertilizer strategies, cultivation, rotation, different plant, grassland soil, urban soil and sand dune, soil recovery in tailings of a lead/zinc mine, chemical pollution, even river pollution (Ekschmitt et al., 2001; Tomar et al., 2009; Hu \& Qi, 2010; Pan et al., 2010; Villenave et al., 2010; Ugarte et al., 2013; Li et al., 2014).

Jujube trees and wheat are of importance as the main economic and food crops in southern Xinjiang. However, no systematic study has been carried out on the nematodes characters of wheat/ jujube and sole jujube systems. So the present study was aimed to characterize the nematode community structure of wheat grown alone field and grown in jujube orchard field to provide an evaluation criterion for further clarifying the mechanism of its difference between monoculture and inter-cropping systems. The objectives of our study in detail were to: 1) Characterize and compare nematode communities in wheat rhizosphere soils under monoculture and intercropping system 2) Evaluate soil food web condition in wheat rhizosphere by means of nematode faunal response to different cropping systems; 3 ) Determine the soil status of wheat rhizosphere that planted in jujube orchard.

\section{Material and Methods}

This study was conducted at a wheat field which was set up in 2009 at Hetian Agricultural Scientific Research Institute (37 $12^{\prime}$ N, 7994' E), Agro-Tech Extension and Service Center of Hetian Prefecture, Xinjiang Uygur Autonomous Region, China. Average annual precipitation is only $35 \mathrm{~mm}$, the potential evaporation is up to $2480 \mathrm{~mm}$. The annual sunshine time is $2470-3000 \mathrm{~h}$, with total solar radiation is $6627 \mathrm{MJ} \mathrm{m}^{-2}$ year $^{-1}$, and annual mean temperature is $13.7^{\circ} \mathrm{C}$, with effective temperature more than $10^{\circ} \mathrm{C}$ reach to $4200{ }^{\circ} \mathrm{C}$. The region has a typical arid climate. And the soil at the site is classified as an Arenosol in the classification system of the Food and Agriculture Organization (FAO).

The experimental design was a single factor field experiment, comprising three replicates of wheat grown alone and three replicates of wheat grown in 6-year-old jujube orchard. Wheat was sown in
October, harvest in June next year. Sole wheat was planted 0.15 $\mathrm{m}$ inter-row and within rows distance. Intercropping system was designed as a replacement series, including 12 rows wheat of 0.15 m inter-row distance plus 2 rows of 6 -year-old jujube trees, the distance between jujube trees and nearest wheat row was $0.6 \mathrm{~m}$. The 6-year-old jujube tree occupied $40 \%$ of the intercropped area and wheat $60 \%$. The density of intercropped wheat was $11,250,000$ plants ha-1. All the three pairs of the treatments plots $(12 \mathrm{~m} \times 40 \mathrm{~m})$ have undergone the same management consistently. All plots were given identical applications of urea $(\mathrm{N})$ at $450 \mathrm{~kg} \mathrm{ha}^{-1}$, and diammonium phosphate $(P)$ at $30 \mathrm{~kg} \mathrm{ha}^{-1}$. All the $P$ fertilizer and a half of the $\mathrm{N}$ were broadcast evenly and incorporated into the top $20 \mathrm{~cm}$ of the soil prior to sowing. The remaining half of the $\mathrm{N}$ fertilizer was applied at the elongation stage. Irrigation was carried out on four occasions on March 25, April 14, May 2, and May 20. Each irrigation application consisted of $90 \mathrm{~mm}\left(900 \mathrm{~m}^{3} \mathrm{ha}^{-1}\right)$. The irrigation practice followed that recommended to farmers by local agronomists. Soil samples were collected during the growing season in May 23, 2011, May 29, 2012 and May 25, 2013, with the wheat in the booting stage and jujube in the sprouting-leaf unfolding stage. Three soil replicate samples (altogether thirty cores) were collected per each treatment plot $(12 \mathrm{~m} \times 40 \mathrm{~m})$, that means per wheat alone and per wheat grown in jujube orchard, with the checkerboard sampling method. Soils from ten cores were mixed to constitute one sample. Each core was taken by using geotome (i. d. $25 \mathrm{~mm}$ ) to a depth of $20 \mathrm{~cm}$.

The samples were stored in individual plastic bags, and immediately transferred to a $4{ }^{\circ} \mathrm{C}$ cold storage. All samples were processed within 7 days of collection. Soil moisture was determined by drying the samples at $105^{\circ} \mathrm{C}$ for $8 \mathrm{~h}$. Soil pH value was measured in a paste of air-dried soil to solution at a ratio of $1: 2$ in $\mathrm{KCl}$ (1 $\mathrm{mol} / \mathrm{L}$ ) by glass electrode. Soil organic matter content was determined by burning dried soil in a muffle furnace at $490^{\circ} \mathrm{C}$ for $8 \mathrm{~h}$. Total nitrogen was measured following micro-Kjeldahl digestion (Bremner \& Mulvaney, 1982). The experiment soil fundamental state was shown in Table.1.

The soil nematodes were extracted from $100 \mathrm{~g}$ fresh soil, using sugar flotation and centrifugation method (Barker et al., 1985). Extracted nematodes were killed at $60{ }^{\circ} \mathrm{C}$ and fixed in $5 \% \mathrm{FA}$ (Formalin acetic acid) for genus identification (Griffiths et al. 1990). The number of nematodes was counted and individuals were identified to genus level, using an upright differential interference microscope (LEICA).

The characteristics of the nematode communities were described by the following approaches: 1) total nematode abundance (individuals per $100 \mathrm{~g}$ dry soil). 2) The classification of trophic groups based on known feeding habits or stoma and esophageal morphology was assigned to: a) Bacterial feeders (BF), b) Fungal feeders (FF), c) Plant feeders (PF), and d) Omnivores-predators

Table 1. Soil environmental conditions under wheat grown alone and grown in jujube orchard field

\begin{tabular}{cccccc}
\hline Sample & Soil moisture (\%) & $\mathrm{pH}$ value & Organic matter $(\mathrm{g} / \mathrm{kg})$ & Total N $(\mathrm{g} / \mathrm{kg})$ & $\mathrm{C} / \mathrm{N}$ \\
\hline $\mathrm{W}$ & 10.99 & 8.00 & 14.32 & 0.87 & 16.49 \\
$\mathrm{JW}$ & 13.81 & 8.11 & 19.69 & 0.69 & 28.48 \\
\hline W: wheat grown alone, JW: wheat grown in jujube orchard &
\end{tabular}


(Om) (Bongers, 1990; Yeates et al., 1993). 3) The classification of nematode colonizer-persister (cp) values based on life strategies according to Bongers (Bongers, 1990; Bongers \& Bongers, 1998; Bongers, 1999). 4) Diversity index: a) Shannon-Weaver index $\left(H^{\prime}\right)$ : $H^{\prime}=-\sum P i$ In $P i$, where pi is the proportion of each taxon in the total population (Shannon \& Weaver, 1949), b) Genus dominance index $(l g): \lg =\sum P P^{2}$, where $p i$ is the proportion of individuals in the $i$-th taxon (Simpson, 1949), c) Evenness index (J'): J' = H' I In (S) (Pielou, 1975), d) Richness index (SR): $S R=(S-1) / \ln (N)$, where $S$ is the number of taxa and $N$ is the number of individuals identified (Yeates \& King, 1997), e) Trophic diversity index (TD): $T D=1 / \sum T i^{2}$, where $T i$ is the proportion of the trophic group $i$ in the nematode community (Heip et al., 1988). 5) Functional index: a) Nematode Channel Ratio (NCR): NCR = BF / (BF + FF) (Yeates 2003), b) Channel index (Cl), Basal Index (BI), Structure Index (SI), Enrichment Index (EI) according to Ferris et al. (Ferris et al. 2001, Ferris\&Matute 2003), c) Wasilewska Index (WI): WI = $(B F+F F) / P P$, the ratio of bacterial feeders plus fungal feeders to plant parasites (Wasilewska 1994). 6) Maturity index: a) Plant parasites index $(P P I): P P I=\sum u i f i$, where vi is the $c-p$ value for the plant-parasitic nematodes to the $i$-th nematode genus and $f i$ is the proportion of genus in the plant-parasitic nematode community (Bongers 1990, Bongers et al. 1997), b) Maturity index (MI): MI= ¿ui fi, where vi is the c-p value for free-living nematodes to the $i$-th nematode genus and $f i^{\prime}$ is the proportion of the genus in the free-living nematode community (Bongers, 1990; Bongers, 1999),

Table 2. Families and respective genera of nematodes found in wheat rhizosphere by grown alone and in jujube orchard

\begin{tabular}{|c|c|c|c|c|c|}
\hline Families & $\mathbf{W}$ & JW & Genera & $\mathbf{W}$ & JW \\
\hline \multirow[t]{2}{*}{ Rhabditidae } & +++++ & +++++ & Rhabditis & $X$ & $X$ \\
\hline & & & Diploscapter & $X$ & $X$ \\
\hline \multirow[t]{4}{*}{ Cephalobidae } & +++++ & +++++ & Cephalobus & $X$ & $X$ \\
\hline & & & Eucephalobus & $X$ & $X$ \\
\hline & & & Acrobeles & $X$ & $X$ \\
\hline & & & Acrobeloides & $X$ & $X$ \\
\hline Plectidae & - & + & Wilsonema & 0 & $X$ \\
\hline Monhysteridae & - & + & Monhystera & 0 & $X$ \\
\hline Prismatolaimidae & + & - & Prismatolaimus & $X$ & 0 \\
\hline Alaimidae & ++ & + & Alaimus & $X$ & $X$ \\
\hline Aphelenchoididae & +++ & + & Aphelenchoides & $X$ & $X$ \\
\hline Aphelenchidae & ++++ & +++++ & Aphelenchus & $X$ & $X$ \\
\hline Diphtherophoridae & - & + & Diphtherophora & 0 & $X$ \\
\hline Tylencholaimidae & + & - & Tylencholaimus & $X$ & 0 \\
\hline Mononchidae & + & - & Mononchus & $X$ & 0 \\
\hline Dorylaimidae & ++ & + & Dorylaimus & $X$ & $X$ \\
\hline Tylenchidae & +++ & ++++ & Tylenchus & $X$ & $X$ \\
\hline Paratylenchidae & + & + & Paratylenchus & $X$ & $X$ \\
\hline Pratylenchidae & + & + & Hirschmanniella & $X$ & $x$ \\
\hline
\end{tabular}

Note: $\mathrm{X}=$ present; $\mathrm{O}=$ absent. $\mathrm{W}$ : wheat grown alone, JW: wheat grown in jujube orchard. +++++: Eu-dominant ( $\geq 10 \%)$; ++++: Dominant $(5 \%-10 \%)$; +++ : Sub-dominant $(2 \%-5 \%) ;++$ : Resident $(1 \%-2 \%)$;

+ : Sub-resident (0\% - 1\%); -: Absent (0\%) c) $P P I / M I=\sum$ ui fi'l $\sum u i$ fi (Bongers et al. 1997), d) $\sum M I=\sum u i P i$, modified maturity index, where vi is the $c-p$ value for free-living and plant parasitic nematodes to the $i$-th nematode genus and $\mathrm{pi}$ is the proportion of the genus in the whole nematode community (Yeates, 1994).

All the data were analyzed through ANOVA by IBM SPSS Statistic v18.0 software package. Mean value (three replicates $x$ three years, $n=9$ ) were compared by paired sampled $t$-test, and difference at $p<0.05$ level were considered as statistically significant.

\section{Results}

A total number of 15 families and 19 genera were present in $\mathrm{W}$ and JW, with only 3 families (Rhabditidae, Cephalobidae, and Aphelenchidae) occurring in common (>10\%). Bacterial feeders dominated nematode communities in both genus composition and proportion (85.22 \% in W and $81 \%$ in JW), consisting of ten genera, Rhabditis, Diploscapter, Cephalobus, Eucephalobus, Acrobeles, Acrobeloides, Wilsonema, Monhystera, Prismatolaimus, and Alaimus. However, Wilsonema and Monhystera were not found in W, while Prismatolaimus was not found in JW. Bacterial feeders that significantly contributing to this trend were Rhabditidae and Cephalobidae, which belong to eu-dominant families. Fungal feeders consisted of four genera, Aphelenchoides, Aphelenchus, Diphtherophora, and Tylencholaimus, respectively. Their contributions to the total nematode communities were $9.92 \%, 11.56 \%$ under W and JW. Diphtherophora was not found in W, while Tylencholaimus was not found in JW. Fungal feeders that significantly contributed to this trend were Aphelenchidae and Aphelenchoididae. Aphelenchidae was eu-dominant family in JW, but dominant in W; Aphelenchoididae was sub-resident family in $\mathrm{JW}$, and sub-dominant in W (Table 2). Plant feeders consisted of three genera, Tylenchus, Paratylenchus, and Hirschmanniella, Their contributions to the total nematode communities were $3.41 \%, 6.82 \%$ under $\mathrm{W}$ and JW, respectively. Omnivore-predators consisted of Mononchus and Dorylaimus, occupied $1.45 \%, 0.62 \%$ of the total nematode communities under $\mathrm{W}$ and $\mathrm{JW}$, and Mononchus was not found in JW (Table 2).

Rhabditidae, Cephalobidae, and Aphelenchidae were the most abundant families in $\mathrm{W}$ soil nematode community, thus were responsible for the trend of different treatment changes. Cephalobidae occupied $54 \%$ of total nematodes in W and increased to $59 \%$ in JW; Rhabditidae occupied $29 \%$ in W and reduced to $22 \%$ in $\mathrm{JW}$; Aphelenchidae occupied $8 \%$ in W and increased to $10 \%$ in JW. Other families account for only $9 \%$ of total nematodes in W and JW (Fig. 1). Mean density of Rhabditidae and Cephalobidae were significantly higher in W than JW, while that of Aphelenchidae did not significant differed between W and JW ( $p>0.05$ ) (Table 3). The mean density of total nematode in $W$ was higher than that in JW, mainly reflected in the greater number of bacterial feeders in W. No significant difference of the mean density of fungal feeders and omnivores-predators were found between W and JW. Whereas, plant feeders were increased in JW in comparison with those in $\mathrm{W}$. In W soil mean number of $\mathrm{cp}-1$ colonizers was 1.79 times greater than that in $\mathrm{JW}$, in addition, the mean number of $\mathrm{cp}-2$ groups was 1.20 times greater than that in JW. On the other side, 

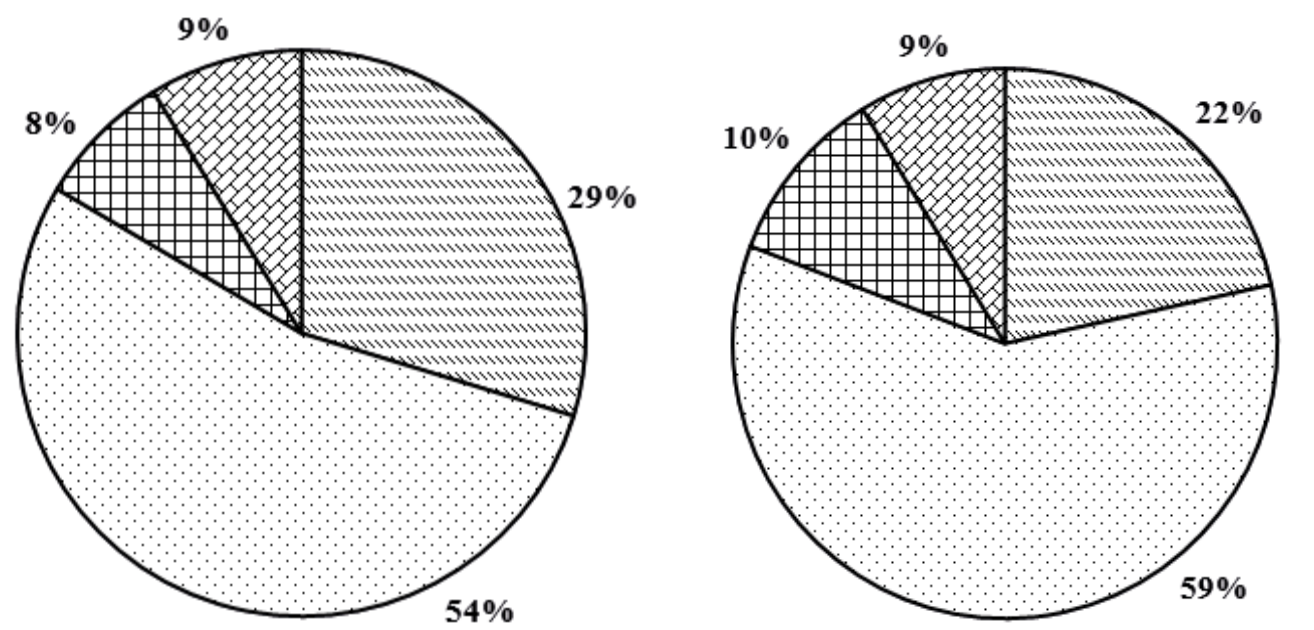

QRhabditidae

口Cephalobidae

日Aphelenchidae

Dother families

Fig. 1. Percentage of most abundant families in wheat rhizosphere soil nematodes by grown alone (A) and grown in jujube orchard (B)

there was no significant difference found in cp-3 and cp-4 groups (Table 3).

No significantly effects were found in Shannon index $\left(H^{\prime}\right)$, genus dominance $(I g)$, evenness $\left(J^{\prime}\right)$, nematode channel ratio $(N C R)$, channel index $(C l)$, basal index $(B I)$, structure index $(S I)$, enrichment index $(E I)$, plant parasitic nematode maturity index $(P P I)$, maturity index $(M I)$ and modified maturity index $(\Sigma M I)$. But significant effects were found in species richness $(S R)$, trophic diversity $(T D)$, Wasilewska index (WI), and the ratio of plant parasitic nematode maturity index to maturity index (PPI/MI). SR and TD were higher in JW than W, while $\mathrm{WI}$ and $P P I / M I$ were lower in JW than W (Table 4).

\section{Discussion}

Soil nematode communities varied in wheat rhizosphere grown alone and grown in jujube orchard. Wilsonema (cp-2) and Monhystera (cp-2) Diphtherophora (cp-3) were only found in JW, while Prismatolaimus (cp-3) Tylencholaimus (cp-4) Mononchus (cp-4) was only found in W. In addition, Wilsonema is known as aquatic nematodes favoring wetter habitats and mulch-influenced environments (Porazinska et al. 1999). Besides, Wilsonema species live in soils that is rich in organic matter, and some of them actually prefer wet sites whereas others tolerate drier soils. So the two factors could act in favour of Wilsonena in JW with more organic matter (Table 1).

Table 3. Density of (a) total nematode populations, (b) nematode feeding groups, (c) colonizer-persister groups, and (d) abundant families in wheat rhizosphere by grown alone and grown in jujube orchard

\begin{tabular}{|c|c|c|c|c|c|c|c|c|c|}
\hline & \multicolumn{2}{|c|}{2011} & \multicolumn{2}{|c|}{2012} & \multicolumn{2}{|c|}{2013} & \multicolumn{3}{|c|}{ Mean } \\
\hline & W & JW & W & JW & W & JW & W & JW & Sig. \\
\hline (a) Total nematodes & 2187 & 1164 & 2052 & 1950 & 2462 & 1809 & 2234 & 1641 & * \\
\hline \multicolumn{10}{|l|}{ (b) Feeding groups: } \\
\hline Bacterial feeders & 1885 & 945 & 1685 & 1556 & 2151 & 1485 & 1907 & 1329 & * \\
\hline Fungal feeders & 252 & 153 & 213 & 217 & 193 & 187 & 219 & 186 & ns \\
\hline Omnivore-predators & 0 & 5 & 80 & 20 & 11 & 7 & 30 & 11 & ns \\
\hline Plant feeders & 50 & 61 & 74 & 157 & 107 & 130 & 77 & 116 & * \\
\hline \multicolumn{10}{|l|}{ (c) Colonizer-persister } \\
\hline $\mathrm{cp}-1$ & 682 & 78 & 239 & 371 & 1142 & 706 & 688 & 385 & * \\
\hline $\mathrm{cp}-2$ & 1492 & 1072 & 1613 & 1515 & 1300 & 1093 & 1468 & 1227 & * \\
\hline$c p-3$ & 13 & 9 & 4 & 32 & 9 & 3 & 9 & 15 & ns \\
\hline $\mathrm{cp}-4$ & 0 & 5 & 196 & 32 & 11 & 7 & 69 & 15 & ns \\
\hline \multicolumn{10}{|l|}{ (d) Abundant families } \\
\hline Rhabditidae & 682 & 78 & 239 & 371 & 1142 & 706 & 688 & 385 & * \\
\hline Cephalobidae & 1203 & 867 & 1342 & 1173 & 1008 & 778 & 1184 & 939 & * \\
\hline Aphelenchidae & 198 & 143 & 190 & 182 & 121 & 175 & 170 & 167 & ns \\
\hline
\end{tabular}

$\mathrm{ns}=$ No significant difference, ${ }^{*}$ refers to significant difference between the $\mathrm{W}$ and $\mathrm{JW}$ at 0.05 level by paired sample $\mathrm{t}$ test.

W: wheat grown alone, JW: wheat grown in jujube orchard 
Table 4. Nematode community parameters: diversity index (a), functional index (b), maturity index (c) under grown alone and grown in jujube orchard

\begin{tabular}{|c|c|c|c|}
\hline & W & JW & Sig. \\
\hline \multicolumn{4}{|c|}{ Diversity index (a) } \\
\hline$H^{\prime}$ & 1.55 & 1.44 & ns \\
\hline $\lg$ & 0.29 & 0.36 & ns \\
\hline$J^{\prime}$ & 0.66 & 0.59 & ns \\
\hline$S R$ & 1.50 & 1.68 & * \\
\hline$T D$ & 1.36 & 1.48 & * \\
\hline \multicolumn{4}{|c|}{ Functional index (b) } \\
\hline NCR & 0.90 & 0.88 & ns \\
\hline $\mathrm{Cl}$ & 9.99 & 17.09 & ns \\
\hline$B I$ & 32.43 & 44.86 & ns \\
\hline$S I$ & 12.43 & 5.50 & ns \\
\hline El & 63.25 & 53.90 & ns \\
\hline WI & 31.20 & 14.21 & * \\
\hline \multicolumn{4}{|c|}{ Maturity index (c) } \\
\hline PPI & 3.07 & 2.08 & ns \\
\hline$M I$ & 1.74 & 1.79 & ns \\
\hline PPI/MI & 1.71 & 1.17 & * \\
\hline$\sum M l$ & 1.78 & 1.81 & ns \\
\hline
\end{tabular}

ns $=$ No significant difference, ${ }^{*}$ refers to significant difference between the $\mathrm{W}$ and JW at 0.05 level by paired sample t test. W: wheat grown alone, JW: wheat grown in jujube orchard

Prismatolaimus (cp-3) Tylencholaimus (cp-4) Mononchus (cp-4) was only found in $\mathrm{W}$, it is indicated that the wheat rhizosphere soil in wheatjujube intercropping system was less suitable for some genera with $\mathrm{cp}-3$ and $\mathrm{cp}-4$ guilds. This result is consistent with previous study which suggested that the density of $\mathrm{cp}-3, \mathrm{cp}-4, \mathrm{cp}-5$ nematodes were negatively correlating with the pollutants (Shao et al., 2008; Korthals et al., 2009).

The lower number of total nematodes in JW, mainly reflected in less abundance of bacterivores and less abundance of $\mathrm{cp}-1$ and сp-2 groups in JW. Rhabditidae and Cephalobidae were the most abundance families in wheat rhizosphere nematode community in monoculture wheat system and jujube/wheat intercropping system, occupying above $20 \%$ and $50 \%$, respectively. The absolute abundance of Rhabditis and Acrobeloides were higher in longterm turfgrass management practices and a field grown tomatoes (Nahar et al., 2006; Cheng et al., 2008). Moreover, Acrobeles and Acrobeloides were also more numerous in tomatoes grown in conventional than in organic systems (Ferris et al., 1997). At the generic or family level, Rhabditidae was the enrichment opportunists, showed a typical r-selected behavior, with sudden and temporal population increase (within $3-4$ weeks), high fecundity, large amount of eggs and high standard metabolism under food-rich conditions (Bongers \& Bongers, 1998). Cephalobidae belonged to cp-2 category which was associated with dry conditions in the soil environment (Griffiths et al., 1995). Rhabditis and Acrobeloides were co-existing species, which had a significant effect on ecosystem function through the creation of additional consumer, decomposer, and symbiotic organism niches. They should be influenced by the root exudates of jujube trees, how and which root exudates influence the soil microorganism and nematodes need the further studies. Lower numbers of Rhabditidae and Cephalobidae means lower fertility of soil and slower decomposition rate of soil food web, which is not benefit for the plant growth.

Shannon index $\left(H^{\prime}\right)$ associated with genus dominance $(I g)$ indicated the diversity of soil detrital food web, with $H^{\prime}$ giving more weight to rare species, while $\lg$ giving greater weight to common species (Freckman \& Ettema, 1993). In detail, higher $H^{\prime}$ and lower Ig indicated greater diversity (Simpson, 1949). J' and SR indicate the evenness and species richness (Yeates \& King, 1997). Trophic diversity $(T D)$ describes diversity of functional groups within the nematode community (Freckman \& Ettema, 1993). Values of TD and $S R$ were significantly increased in JW, mainly because of lower percentages of bacterivores. No significant differences in the rest of diversity indices between the two systems. It is concluded that wheatjjujube intercropping system had relatively less affect on the diversity in wheat rhizosphere soil food web.

Ecological indices such as basal index $(B I)$, channel index $(C I)$, structural index $(S I)$, and enrichment index (El) may provide insight to whether the nematode community structure is in stressed, nutrients enriched, stable structured or decomposition environments, and provide information on the dynamics of the soil food web (Ferris et al., 2001). Moreover, nematode channel index (NCR) indicated the decomposition processes in soil (Yeates, 2003). Unfortunately, these indices were not sensitive to show any difference between wheat monoculture system and wheatjujube intercropping system in wheat rhizosphere soil. The values of Wasilewska index (WI) could present substantial changes in the trophic structure of the nematode community, in this study was greater than 14 , which were higher than tillage and wheat residue field $(4-12)$ (Liang et al., 2005), soybean field (1.01 - 8.80) (McSorley \& Frederick, 1996), and Gansu wheat field (0.40) (Liu et al. 2006). Bongers et al. (1997) reported that PPIIMI were higher in the intensively managed agricultural systems than natural undisturbed habitats, and effects of slight nutrient disturbances are indicated by a value of up to 1.2. Lower PPIIMI indicate barren soil food web and less plant productions, and showed that wheatjjujube intercropping system could emaciate the soil conditions. Lower values of PPII $\mathrm{Ml}$ suggested less plant production underground in JW, in line with decreased root length density and root surface area density in JW (Zhang et al., 2013).

Most studies on intercropping have focused on resource utilization, including water, light, and nutrients (Mclntyre et al., 2001; Inal et al., 2007). It has been shown that the interspecific interactions in the rhizosphere facilitate $\mathrm{N}$ and $\mathrm{P}$ uptake in intercropping systems, resulting in substantial yield advantage compared with sole cropping (Li et al., 2010). Our obtained result also showed that wheat/ jujube intercropping system increased the content of soil organic material (Table 1). It has been reported that jujube/wheat intercropping significantly decreased growth and yield of wheat and jujube in south Xinjiang, China, however, both of Land equivalent ratio (LER) were greater than 1.0, that means intercropping is advantageous (Song et al., 2007; Zhang et al., 2013). The difference between monoculture jujube and wheat/jujube intercropping system in jujube rhizosphere soil need further studies (in preparation). 


\section{Conclusion}

Wheat grown in jujube orchard could negatively affect the nematode community in wheat rhizosphere soil. Wasilewska index $(W I)$ and PPIIMI could provide useful information about the effects of monoculture and intercropping system on soil nematode fauna, lower $W I$ and $P P I / M I$ in wheat/jujube intercropping system might indicate the less fertile soil food web with fungal decomposition channels than wheat monoculture system.

\section{Acknowledgements}

This work was financially supported by the Chinese ministry of agriculture (Project No. 201003043-02). The authors wish to express their appreciation to anonymous reviewer for valuable comments.

\section{References}

Barker, K.R., Carter, C.C., Sasser, J.N. (1985): An advanced treatise on Meloidogyne, Methodology, Vol. 2. North Carolina State University Graphics. Raleigh, NC, 223 pp.

Bernard E. C. (1992): Soil nematode biodiversity. Biol. Fert. Soils, 14: $99-103$

Berry, S.D., Dana, P., Spaull, V.W., Cadet, P. (2009): Effect of intercropping on nematodes in two small-scale sugarcane farming systems in South Africa. Nematropica, 39: 11 - 33

BONGERS, T. (1990): The maturity index: an ecological measure of environmental disturbance based on nematode species composition. Oecologia, 83: 14 - 19. DOI: 10.1007/BF00324627

BONGERS, T. (1999): The Maturity Index, the evolution of nematode life history traits, adaptive radiation and cp-scaling. Plant Soil, 212: $13-22$

BonGeRs, T., Bongers, M. (1998): Functional diversity of nematodes. Appl. Soil Ecol., 10: 239 - 251

Bongers, T., Van Der Meulen, H., Korthals, G. (1997): Inverse relationship between the nematode maturity index and plant parasite index under enriched nutrient conditions. Appl. Soil Ecol., 6: 195 - 199. DOI: 10.1016/S0929-1393(96)00136-9

Bremner, M. C., Mulvaney, C. S. (1982): Methods of Soil Analysis. Part 2. Chemical and Microbiological Properties. American Society for Agronomy. Madison, WI, USA, 595 - 624 pp.

Chang, J.T., Zhang, C.C., QIAO, B.Y., LI, B.Y. (2012): Ecological efficiency of intercropping wheat with Chinese jujube. J. Fruit Sci., 29: 274 - 277 (In Chinese)

Cheng, Z., Grewal, P.S., Stinner, B.R., Hurto, K.A., Hamza, H.B. (2008): Effects of long-term turfgrass management practices on soil nematode community and nutrient pools. Appl. Soil Ecol., 38: 174 - 184. DOI: 10.1016/j.apsoil.2007.10.007

EKSCHMITT, K., BAKONYI, G., Bongers, M., Bongers, T., BOStrom, S., Dogan, H., Harrison, A., Nagy, P., O'donnell, A.G., Papatheodorou E.M. (2001): Nematode community structure as indicator of soil functioning in European grassland soils. Eur. J. Soil Biol., 37: 263 - 268. DOI: 10.1016/S1164-5563(01)01095-0

FerRIS, H., Bongers, T. De GoEdE, R.G.M. (2001): A framework for soil food web diagnostics: extension of the nematode faunal analysis concept. Appl. Soil Ecol., 18: 13 - 29. DOI: 10.1016/ s0929-1393(01)00152-4

FerRIs, H., Matute, M.M. (2003): Structural and functional succession in the nematode fauna of a soil food web. Appl. Soil Ecol., 23: 93 - 110. DOI: 10.1016/S0929-1393(03)00044-1

Ferris, H., Venette, R., Lau, S. (1997): Population energetics of bacterial-feeding nematodes: carbon and nitrogen budgets. Soil Biol. Biochem., 29: 1183 - 1194. DOI: 10.1016/S00380717(97)00035-7

FreckMAn, D.W., EtTemA, C.H. (1993): Assessing nematode communities in agroecosystems of varying human intervention. Agric., Ecosyst. \& Environ., 45: 239 - 261. DOI: 10.1016/01678809(93)90074-Y

Griffiths, B.S., Boag, B., Neilson, R., Palmer, L. (1990): The use of colloidal silica to extract nematodes from small samples of soil or sediment. Nematologica, 36, 1: $465-473$

GRIFFITHS, B.S., Young, I.M., CaUL, S. (1995): Nematode and protozoan population dynamics on decomposing barley leaves incubated at different soil matric potentials. Pedobiologia, 39: $454-461$ Heip, C., Herman, P.M.J, Soetaert, K. (1988): Introduction to the study of meiofauna. Data processing, evaluation and analysis. Smithsonian Institution Press. Washington D.C., 197 - 231 PP.

Hu, C., QI, Y.C. (2010): Abundance and diversity of soil nematodes as influenced by different types of organic manure. Helminthologia, 47: 58 - 66. DOI: 10.2478/s11687-010-0009-8

Inal, A., Gunes, A., Zhang, F., Cakmak, I. (2007): Peanut/maize intercropping induced changes in rhizosphere and nutrient concentrations in shoots. Plant physiol. Bioch., 45: 350 - 356. DOl: 10.1016/j.plaphy.2007.03.016

Korthals, G.W., Bongers, T., Kammenga, J.E., Alexiev, A.D., LeXMOND, T.M. (2009): Long-term effects of copper and ph on the nematode community in an agroecosystem. Environ. Toxicol. Chem., 15: 979 - 985. DOI: 10.1002/etc.5620150621

Li, H.G., Shen, J.B., Zhang, F.S., Marschner, P., Cawthray, G., RenGEL, Z. (2010): Phosphorus uptake and rhizosphere properties of intercropped and monocropped maize, faba bean, and white lupin in acidic soil. Biol. Fert. Soils, 46: 79 - 91. DOI: 10.1007/s00374009-0411-X

LI, X.Y., LIU, Q.Z., LIU, Z.L., ShI, W.P., Yang, D.W., Tarasco, E. (2014): Effects of organic and other management practices on soil nematode communities in tea plantation: a case study in southern China. J. Plant Nutr. Soil Sc., 177: 604 - 612. DOI: 10.1002/ jpln.201300610

Liang, W.J., Lavian, I., Pen Mouratov, S., Steinberger, Y. (2005): Diversity and dynamics of soil free-living nematode populations in a Mediterranean agroecosystem. Pedosphere, 15: $204-215$ LIU, J.Q, HALIK, W., WANG, G.S., KASIM, Y. (2012): Study on temporal and spatial distribution rules of characteristic fruit industry resources in Xinjiang. Agr. Res. Arid Areas, 30: 230 - 236 (In Chinese)

LIU, Y., HUA, J., JIANG, Y., LI, Q., WeN, D. (2006): Nematode communities in greenhouse soil of different ages from Shenyang suburb. Helminthologia, 43: 51 - 55. DOI: 10.2478/s11687-006-0010-4 Mcintyre, B.D., Gold, C.S., KashaluA, I.N., Ssal, H., Night, G., BwaMIKI, D.P. (2001): Effects of legume intercrops on soil-borne pests, biomass, nutrients and soil water in banana. Biol. ert. Soils, 34: $342-348$ 
Mcsorley, R., Frederick, J.J. (1996): Nematode community structure in rows and between rows of a soybean field. Fund. Appl. Nematology, 19: $251-262$

Nahar, M.S., Grewal, P.S., Miller, S.A., Stinner, D., Stinner, B.R., Kleinhenz, M.D., Wszelaki, A., Doohan, D. (2006): Differential effects of raw and composted manure on nematode community, and its indicative value for soil microbial, physical and chemical properties. Appl. Soil Ecol., 34: 140 - 151. DOI: 10.1016/j.apsoil.2006.03.011

NeHER, D.A. (2001): Role of nematodes in soil health and their use as indicators. J. Nematol., 33: $161-168$

Pan, F.J., Mclaughlin, N.B., Yu, Q., Xue, A.G., Xu, Y.L., Han, X.Z., LI, C.J., ZHAO, D. (2010): Responses of soil nematode community structure to different long-term fertilizer strategies in the soybean phase of a soybean-wheat-corn rotation. Eur. J. Soil Biol., 46: 105 - 111. DOI: 10.1016/j.ejsobi.2010.01.004

Pielou, E.C. (1975): Ecological diversity. New York: John Wiley, 165 pp.

Porazinska, D.L., Duncan, L.W., Mcsorley, R., Graham, J.H. (1999): Nematode communities as indicators of status and processes of a soil ecosystem influenced by agricultural management practices. Appl. Soil Ecol., 13: 69 - 86. DOI: 10.1016/S0929-1393(99)00018-9 RaO, M.S., RaO, C.A.R., SRinivas, K., Pratibha, G., SekHar, S.M.V., VANI, G.S., VeNKATESWARLU, B. (2012): Intercropping for management of insect pests of castor, Ricinus communis, in the semi-arid tropics of India. J. Insect Sci., 12: 1 - 10

Santorufo, L., Van Gestel, C.A. M., Rocco, A., Maisto, G. (2012): Soil invertebrates as bioindicators of urban soil quality. Environ. Pollut., 161: 57 - 63. DOI: 10.1016/j.envpol.2011.09.042

Shannon, C.E., Weaver, W. (1949): The Mathematical Theory of Communication. Urbana: University of Illinois Press, $117 \mathrm{pp}$.

Shao, Y.H., Zhang, W.X., Shen, J.C., Zhou, L.X., XIA, H.P., Shu W.S., Ferris, H., Fu, S.L. (2008): Nematodes as indicators of soil recovery in tailings of a lead/zinc mine. Soil Biol. Biochem., 40: 2040 - 2046. DOI: 10.1016/j.soilbio.2008.04.014

SIDDIQUI, M.A., Alam, M.M. (1987): Control of plant parasitic nematodes by intercropping with Tagetes minuta. Nematol. medit, 15 : $205-211$

SIMPSON, E.H. (1949): Measurement of diversity. Nature, 163: 688 Song, Y.N, Zhang, F.S., Marschner, P., Fan, F.L., Gao, H.M., Bao, X.G., Sun, J.H., LI, L. (2007): Effect of intercropping on crop yield and chemical and microbiological properties in rhizosphere of wheat (Triticum aestivum L.), maize (Zea mays L.), and faba bean (Vicia faba L.). Biol. Fert. Soils, 43: 565 - 574. DOI: 10.1007/ s00374-006-0139-9

TOMAR, V.V.S., ZHANG, X.K., LI, Q., JIANG, Y., LIANG, W.J., (2009): Distribution of soil nematode communities along a section of Shen-Ha Highway. Helminthologia, 46: 241 - 246. DOI: 10.2478/ s11687-009-0044-5

UGARTE, C.M., ZABORSKI, E.R., WANDER, M.M. (2013): Nematode indicators as integrative measures of soil condition in organic cropping systems. Soil Biol. Biochem., 64: 103 - 113. DOI: 10.1016/j. soilbio.2013.03.035

Villenave, C., Saj, S., Pablo, A. L., Sall, S., Duigal, D., Chotte, J.L. BonzI, M. (2010): Influence of long-term organic and mineral fertilization on soil nematofauna when growing Sorghum bicolor in Burkina Faso. Biol. Fert. Soils, 46: 659 - 670. DOI: 10.1007/ s00374-010-0471-y

WASILEWSKA, L. (1994): The effect of age of meadows on succession and diversity in soil nematode communities. Pedobiologia, 38: $1-11$

YeAtes, G.W., Bongers, T. (1999): Nematode diversity in agroecosystems. Agric., Ecosyst. \& Environ., 74: 113 - 135. DOI: 10.1016/ B978-0-444-50019-9.50010-8

Yeates, G.W., Bongers, T., De Goede, R. G.M., Freckman, D.W., GEORGIEVA, S.S. (1993): Feeding habits in soil nematode families and genera-an outline for soil ecologists. J.Nematology, 25: 315 $-331$

YeATES, G.W., KING, K.L. (1997): Soil nematodes as indicators of the effect of management on grasslands in the New England Tablelands (NSW): comparison of native and improved grasslands. Pedobiologia, 41: 526 - 536

YEATES, G.W. (2003): Nematodes as soil indicators: functional and biodiversity aspects. Biol. Fert. Soils, 37: 199 - 210. DOI: 10.1007/ s00374-003-0586-5

YEATES, G.W. (1994): Modification and qualification of the nematode maturity index. Pedobiologia, 38: 97 - 101

Zhang, W., Ahanbieke, P., Wang, B. J., Xu, W.t., Li, L.H., Christie, P., LI, L. (2013): Root distribution and interactions in jujube tree/ wheat agroforestry system. Agroforest. Syst., 87: 929 - 939. DOI: 10.1007/s10457-013-9609-x

ZHAO, X.Z., LU, J.B. (2004): Research progress in agroforestry system. Chin. J. Ecol., 23: 127 - 132 (In Chinese) 